\title{
"The policy-led sustainability and financial performance linkage in the banking sector: case of Bangladesh"
}

\begin{tabular}{|c|c|}
\hline \multirow{5}{*}{ AUTHORS } & Samiul Parvez Ahmed (iD https://orcid.org/0000-0001-9273-6581 \\
\hline & Sarwar Uddin Ahmed iD https://orcid.org/0000-0002-6743-2794 \\
\hline & Mohammad Fahad Noor iD https://orcid.org/0000-0003-1435-9471 \\
\hline & Zaima Ahmed (D https://orcid.org/0000-0002-8835-7148 \\
\hline & Uttam Karmaker (D https://orcid.org/0000-0003-3204-9362 \\
\hline ARTICLE INFO & $\begin{array}{l}\text { Samiul Parvez Ahmed, Sarwar Uddin Ahmed, Mohammad Fahad Noor, Zaima } \\
\text { Ahmed and Uttam Karmaker (2019). The policy-led sustainability and financial } \\
\text { performance linkage in the banking sector: case of Bangladesh. Banks and Bank } \\
\text { Systems, 14(4), 89-103. doi:10.21511/bbs.14(4).2019.09 }\end{array}$ \\
\hline DOI & http://dx.doi.org/10.21511/bbs.14(4).2019.09 \\
\hline RELEASED ON & Tuesday, 10 December 2019 \\
\hline RECEIVED ON & Wednesday, 11 September 2019 \\
\hline \multirow[t]{2}{*}{ ACCEPTED ON } & Thursday, 14 November 2019 \\
\hline & $((c)) \overline{E Y}$ \\
\hline LICENSE & $\begin{array}{l}\text { This work is licensed under a Creative Commons Attribution } 4.0 \text { International } \\
\text { License }\end{array}$ \\
\hline JOURNAL & "Banks and Bank Systems" \\
\hline ISSN PRINT & $1816-7403$ \\
\hline ISSN ONLINE & $1991-7074$ \\
\hline PUBLISHER & LLC "Consulting Publishing Company "Business Perspectives" \\
\hline FOUNDER & LLC "Consulting Publishing Company "Business Perspectives" \\
\hline
\end{tabular}

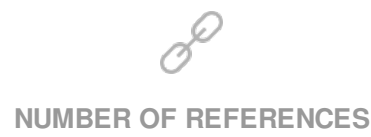

52
NUMBER OF FIGURES

2
NUMBER OF TABLES

8

(C) The author(s) 2022. This publication is an open access article. 


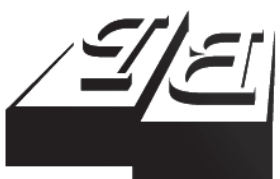

BUSINESS PERSPECTIVES

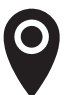

LLC "CPC "Business Perspectives” Hryhorii Skovoroda lane, 10, Sumy, 40022, Ukraine

www.businessperspectives.org

Received on: $11^{\text {th }}$ of September, 2019 Accepted on: $14^{\text {th }}$ of November, 2019

(C) Samiul Parvez Ahmed, Sarwar Uddin Ahmed, Sarwar Uddin Ahmed, Mohammad Fahad Noor, Zaima Ahmed, Uttam Karmaker, 2019

Samiul Parvez Ahmed, Ph.D., Associate Professor, School of Business, Department of Finance, Independent University, Bangladesh.

Sarwar Uddin Ahmed, Ph.D., Professor, School of Business, Department of Finance, Independent University, Bangladesh.

Mohammad Fahad Noor, MSc in Business Finance, Lecturer, School of Business, Department of Finance, Independent University, Bangladesh,

Zaima Ahmed, MSc in Finance and Development, Lecturer, School of Business, Department of Finance, Independent University, Bangladesh.

Uttam Karmaker, MBA, Graduate Assistant, School of Business, Department of Finance, Independent University, Bangladesh.

\section{(c) (1)}

This is an Open Access article, distributed under the terms of the Creative Commons Attribution 4.0 International license, which permits unrestricted re-use, distribution, and reproduction in any medium, provided the original work is properly cited.
Samiul Parvez Ahmed (Bangladesh), Sarwar Uddin Ahmed (Bangladesh), Mohammad Fahad Noor (Bangladesh), Zaima Ahmed (Bangladesh), Uttam Karmaker (Bangladesh)

\section{THE POLICY-LED SUSTAINABILITY AND FINANCIAL PERFORMANCE LINKAGE IN THE BANKING SECTOR: CASE OF BANGLADESH}

\begin{abstract}
Researchers in developed countries argue that banks should be free to decide about their sustainability initiatives without the interference from regulators. However, researchers in developing countries tend to think differently. This study aimed to focus on this argument by examining the linkage between sustainability and financial performance (SFP) aided through regulatory policy guidelines. In doing so, a comparative study was conducted between 2012 and 2018 to compare the pre- and post-status of SFP due to implementation of policy measures. Environmental, social and governance (ESG) scores were calculated and related with financial performance (return on assets) through regression analysis. The sample data includes 30 private commercial banks (PCBs) in Bangladesh. The analysis of the data shows that during these years, the overall sustainability performance, i.e., environmental, social and governance scores of the banks increased by 33 percent. However, the transformation of this performance into better financial performance could not been established even when age and size were taken into account. The current turbulent state of the banking sector due to growing non-performing loan has been identified as the single most influential factor for this neutral result. Research findings suggest that policy guideline initiatives do have a positive impact on bank sustainability. However, exogenous factors, such as political interference, may appease, deviate and prolong its impact on financial performance. This work will enhance the understanding of academics and policy-makers about the feasibility and impact of the policy-led sustainability model in the banking sector, particularly in developing countries.
\end{abstract}

Keywords

JEL Classification policy-led sustainability, financial performance, environmental, social and governance (ESG) risks, banking sector, developing country

G20, G21, Q56

\section{INTRODUCTION}

The alignment of economic goals and sustainable development has become a worldwide problem. A number of actors have been involved in mitigating the challenge towards the pathway of sustainable development. One of the most difficult issues has been to deal with environmental degradation caused by industrial sector. Against the backdrop of this issue, many policies and stances have been adopted across the world by endowing resources and investment in green and climate resilient policies (Volz, 2018). Finance sector has been designated as one of the most crucial actors in mitigating the growing challenge towards a green transformation. According to Volz et al. (2015, p. 2), Green Finance is defined as "...all forms of investment or lending that consider environmental effect and enhance environmental sustainability". Particularly, understanding the dynamics of Environmental, Social and Governance (ESG) risks is a crucial concept in alleviating the socio-environmental and governance issues and enhancing robust 
green financing processes. Integrating ESG factors in the financial sector of an economy has been a recent phenomenon across the globe. The intensity of this integration varies across regions and countries. Fewer financial institutions have been able to integrate ESG factors into their investment and lending programs in Asia. Over the years, it has been seen that banking industry across the globe has experienced rather a tarnishing reputation due to breakdowns in governance and public breach of trust. It may seem that the banking sector has no direct impact on the environment as it does not pollute air, water or land; it does not produce any physical goods/products. However, it is widely accepted that the banking sector does relate to the linkage between the socio-environmental issues and industrialization as banks act as a major source of financing for firms (Smith, 1993). Particularly, through lending process, banking sector has become one of the responsible parties in tarnishing socio-environmental justice in light of the capitalism vs. "green" discourse. Thus, in terms of responsible investment, it is widely argued that banks can play a major role in ensuring the firms being "green" or compliant with the ESG factors through responsible credit management process of the banks. Besides, compliance with ESG factors is no more only a concern for the regulatory bodies; rather firms including their stakeholders (e.g., banks) are becoming aware of the fact that the investors, while taking investment decisions, consider the responsible behaviors of firms towards their environment and society. Hence, apart from regulatory issues, market reputation also drives firms and banks towards responsible behavior. Thus, to reduce the growing concern for the banking industries, policy makers and development entities have developed integration policies of environmental and social responsibility in various ways.

In Bangladesh, since mid-1990s, there has been an increase in policy development and implementation in addressing social and environmental issues. The history of socio-environmental policy of Bangladesh shows that Corporate Social Responsibility (CSR) philosophy is considered the basis for policy formulation when expected responsible behaviors of firms are seen as part of their CSR initiatives. It should be noted that the capital market is not yet the first choice as financing option for firms in Bangladesh, rather, the banking sector still dominates financial market. Hence, the ESG policy guidelines are primarily focused on the financial institutions, which subsequently act as a mechanism for controlling the responsible behavior of firms. Or, in other words, the established policies are to bring socio-environmental justice by the firms through the credit approval and risk management activities (where ESG policy guidelines are embedded) of the financial sector. Particularly, the first step towards addressing environmental aspects in Bangladeshi financial sector started in 1995, when the Department of Environment (DOE) issued Environmental Conservation Act. Since then, with several phases of development and amendment (discussed in detail later) of a range of guidelines and rules issued by the central bank, Bangladesh Bank (BB), the socio-environmental policy framework has taken a firm shape in 2017, when Guidelines on Environmental \& Social Risk Management (ESRM) for Banks and Financial Institutions in Bangladesh were issued by the Bangladesh Bank. Henceforth, there has been a significant increase in bank's engagement in various social indicators through direct monetary expenditure, social investment, financial inclusion and environmental banking.

Given the above argument, it is clear that the sustainability of banks depends on the firms' performance which largely depends on the ESG factors provided by the banking sector through the credit approval process. Thus, it is crucial to assess the relationship between banks' response to the ESG policy framework and its impact on their sustainability. In many cases, there is a lack of research into assessing the nature of the relationship between the response to ESG policy guidelines and sustainability of banks in the context of developing countries. It should be noted that the authors, based on the established policy frameworks in Bangladesh till 2011, conducted a study to assess the impact of ESG on the performance of banks in Bangladesh. In this study, a modest attempt has been taken to assess the linkages between ESG and sustainability of banks considering the comprehensive policy implementation period in the context of Bangladesh. Moreover, given the major policy developments taken place before and after 2012, a comparative analysis well help to find out the impact of changes in CSR policies on the sustainability of the banking sector in Bangladesh. 


\section{LITERATURE REVIEW}

Sustainable banking has long been an area of research that not only deals with efficient housekeeping practices, such as energy saving or reducing paper or material consumption, but also includes the truly significant impact it can have on the sustainable development of the society and environment. Corporate entities that take some CSR measures would engage in "actions that appear to further some social good, beyond the interests of the firm and that which is required by law" (McWilliams \& Siegel, 2001, p. 117). This, in processes and motivations, is consistent with the stakeholder theory that delineates the effects of corporate activity, and the means to achieve these effects centered on the involved stakeholders. Ultimately, CSR is work that goes beyond regular business activity, thus not contributing directly to winning or losing, and can be understood as an added value as a public good instead (McWilliams \& Siegel, 2001).

Banks can actively guide the development of their commercial networks into a sustainable direction either through a credit management process that embeds ESG factors within it or through the usage of specially designed products such as green credits, loans and investment (Jeucken \& Bouma, 2001). Sustainable banking and/or Socially Responsible Investment (SRI), which is considered to be a variation of Corporate Social Responsibility (CSR), where ESG is part of it, are usually measured through Corporate Social Performance (CSP). Salzman, Ionescu-somers, and Steger (2005) presented the framework of CSP with the integration of social and environmental factor. There has been vast research on the interaction between financial performance and ESG factors examined separately (Gompers, Ishii, \& Metrick, 2003; Waddock \& Graves, 1997; Benabou \& Tirole, 2010) or in combination (Gillan et al., 2010). Although there are several studies that attempt to examine the nature of the relationship between CSR or ESG and performance, however, due to the complex nature of the constructs, the findings are often found to be positive (Graves \& Waddock, 1994; McGuire, Sundgren, \& Schneeweis, 1988; McGuire, Schneeweis, \& Branch, 1990; Simpson \& Kohers, 2002), nega- tive (Preston \& O'Bannon, 1997) and even inconclusive (Coffey \& Frywell, 1991; Aupperle, Carroll, \& Hatfield, 1985; Shane \& Spicer, 1983).

There were studies that found a negative relationship, advocating the idea of trade-off hypothesis, reflecting the neoclassical argument that money is an absolute primary goal of companies and that any Bangladeshi bank in social responsibility efforts would only decrease the profits and unnecessarily reduce profits (Friedman, 1962). Building on views pointing to managers following selfish ideals and enriching themselves to the detriment of share and stakeholders (Weidenbaum \& Vogt, 1987; Posner \& Schmidt, 1984), the managerial opportunism theory (Preston \& O'Bannon, 1997) states that, when backed by solid financial returns, managers cut back on social programs and expenditures furthering short-term private increases. Conversely, if financial performance is weak, social programs are used as a 'smoke screen' to divert from the real reasons of business deterioration. Both the trade-off and opportunism hypotheses can act in combination with what is called negative synergy (Preston \& O'Bannon, 1997). Also, Gompers, Ishii, and Metrick (2003) found a negative relationship between poor governance and equity returns in the U.S. market.

There are also arguments that the direct observable relationship is hard to detect between CSR initiatives and performance. While rationalizing inconclusive results, it is often argued that the inherent complex nature of the CSR constructs poses challenges to measure them in an objective way and, moreover, it may be difficult to separate the confounding effects of CSR on performance (Waddock \& Graves, 1997). In a recent large-scale meta-study, CSR is shown to be reflected in the market mechanism of SRI; both phenomena are inherently connected but in an ambiguous manner. Revelli and Viviani (2015) sought to draw a line under the back and forth of 20 years of opinions in SRI research. Past research results differed widely in their expression of financial performance of SRI and were dependent primarily on the research methodology. After screening 85 different studies and 190 experiments, the authors argue that investing in SRI neither yields a real cost nor ben- 
efits in financial terms. The interest, from now on, should lie on the additional, extra financial gains of SRI.

Irrespective of the negative and ambiguous results, a great deal of research found a positive relationship between CSR, CSP or ESG factors and financial performance (FP) of firms. Preston and O'Bannon (1997) conducted a large empirical study of causal sequences between financial and social performance. They found no negative connections between financial and social performance in contrast to the underlying assumptions mentioned earlier in terms of the apparent negative linkages. Instead, their study (Preston \& O'Bannon, 1997) showed a positive or at least neutral linkage between financial and social performance. Similarly, several studies found a positive relationship between CSP and FP on the ground that CSP leads to reduced transaction expenses (Ruf, Muralidhar, Brown, Janney, \& Paul, 2001); reduced firm's financial risk (Ullmann, 1985); good images to customers (McGuire et. al., 1988); higher motivation to employees with positive image (Turban \& Greening, 1997; Moskowitz, 1972); reduced possibility of regulatory penalty (McGuire et. al., 1988); enhanced access to important resources (Cochran \& Wood, 1984) and creating intangible value (Hull \& Rothenberg, 2008).

As mentioned earlier, there is dearth of studies examining a relationship between ESG and FP in the context of a developing country such as Bangladesh. Few works can be traced where efforts are made to analyze the area. Uchida, Ahmed, and Aabed (2011) examined relationships between firms' performance and banking sector governance. They found a positive though not statistically significant relationship between them. In another study, it was found that the incorporation of ESG factors in the credit management process of the Bangladeshi banking sector could reduce the default rates (Weber, Hoque, \& Islam, 2015). In a recent study (self citation), the authors, based on data till 2011, found a somewhat positive relationship between ESG and FP though the results may have different implications compared to the recent policy developments in the banking sector of Bangladesh.

\subsection{Development of the sustainability policy framework in the banking sector of Bangladesh}

To address growing global environmental issues, the Department of Environment (DOE) of Government of Bangladesh initiated the first regulatory policy framework, Environment Conservation Act (ECA), in 1995. According to the ECA, in 1997, all the commercial banks of Bangladesh were directed by the Central Bank of Bangladesh, Bangladesh Bank, to ensure environmental pollution issues to be addressed properly before financing new projects or even approving/extending working capital loans to existing firms. Subsequently, later in 2008, Bangladesh Bank stressed on incorporating Corporate Social Responsibilities (CSR) in the financial sector operations. It is often criticized that lending process of the financial sector lacks a clear and precise framework provided by the Bangladesh Bank to address environmental and CSR aspects (Habib, 2010). However, in April 2010, Bangladesh Bank's initiative to encourage such practices through publicly disclosing annual evaluations of CSR practices of the scheduled banks in Bangladesh is commendable (DOS Circular No. 1, 2008). With an objective to track the progress in mainstreaming CSR practices in the banking sector, in 2010, Bangladesh Bank published the first "Review of CSR Initiatives in Banks (2008 \& 2009)", where Bangladesh Bank highlighted that more than $95 \%$ of the banks started implementing the CSR practices in "some form or other" (Bangladesh Bank, 2010). However, the ways banks participated in the CSR practices were critiqued on the ground that "CSR expenditures of banks have thus far largely been in the form of passive grants and donations" (Bangladesh Bank, 2010) and failed to take more proactive and beyond regulatory initiatives. Subsequent review report of 2010 titled "Review of CSR Initiatives in Banks (2010)" reported an enhanced picture of CSR practices in the banking sector. Particularly, the report identified that the banks, apart from direct expenditure, were also involved in "CSR practices focusing on social and financial inclusion of excluded and under served population segments and economic sectors, as also on environmental concerns" (Bangladesh Bank, 2011c, p. 1). 
At the same time, in response to the market need for more clear-cut policies in CSR and environmental aspects, Bangladesh Bank issued two policy papers in 2011: "Environmental Risk Management (ERM) Guidelines for Banks and Financial Institutions in Bangladesh" (Bangladesh Bank, 2011a) and "Policy Guidelines for Green Banking” (Bangladesh Bank, 2011b). The objective of the two policy papers was to embed CSR, green banking and ESG risk management in the banking process in an accountable and standardized manner. Particularly, the objective of the ERM guidelines is to "internalize the risk that a deteriorating environment poses on the interests of the financial institution" (Bangladesh Bank, 2011a). From the similar view point, while highlighting the environment degradation issues (e.g., air, water, land) of the country, Bangladesh Bank proposed green banking policies to be incorporated in a structured and standardized manner within banking sector in three phases. In Phase I, banks are asked to establish their own green banking policies and align internal resources to address them; establish a high-powered committee of directors to oversee "environmental policies, strategies and program" (Bangladesh Bank, 2011b) and develop separate Green Banking Unit within each bank (Bangladesh Bank, 2011b). In Phase II, banks are required to develop sector (e.g., Agro-Farming, Construction and Housing, Fisheries) specific green banking strategies and respective timelines to implement them. Finally, in Phase III, banks are motivated to develop innovation green products to mitigate negative consequences of environmental degradation. In 2012, Bangladesh Bank issued another circular (DFIM Circular Letter No. 02) with the focus on mainstreaming gender equality as part of the CSR initiatives developed for the financial institutions. Setting a deadline, December 2013, the policy guidelines broadly illustrated ways to adapt environmental factors within the operations of the commercial banks (Byron, 2011). Besides, to motivate the banks, compliance with the policy framework was interweaved positively with rewards such as enhancement of score in CAMELS rating; revised assessment of CAR (capital adequacy ratio); prioritization of expansions of branch banking; and public disclosure of raking of ESG compliant banks. In case of the governance issue, Securities and Exchange Commission (SEC) brought amendment to its governance ordinance in August 2012, where focus was on in streamlining policies in forming board of directors, internal and external audit committees and clearer guidelines for reporting and compliance of corporate governance. In 2017, Bangladesh Bank issued "Guidelines on Environmental and Social Risk Management (ESRM) for Banks and Financial Institutions in Bangladesh", where the objective was to incorporate environmental and social issues in the credit management process in such a way that the risks of such factors could be factored in calculating probability of default of a credit Bangladesh Bank, 2017). Primarily, this policy framework emphasized various social parameters, which were absent in previous policy guidelines, and proposed methods to quantitatively measure environmental and social factors in the credit approval process (see Table 1 for a summary).

The above discussion about the history and development of several CSR policies in the financial sector of Bangladesh clearly delineates an interesting subject of study where examination of the nature of the ESG policy frameworks and their impact on the bank performance is necessary. As mentioned earlier, the authors already conducted a research in this area (Specify the source) though the study was focusing on the policy developments till 2011; this study incorporates the subsequent policy movements till 2017, which are considered having a significant influence on the performance of the banks in relation to CSR initiatives in the country.

\section{EMPIRICAL MODEL AND HYPOTHESIS}

Given the theoretical arguments presented in the literature review, it can be argued that in many cases, embracing to CSR or ESG initiatives brings positive change to financial performance for many organizations. Specifically, irrespective of irregularities, much previous empirical evidence revealed that a positive relationship exists for various aspects of CSR initiatives and CSP or FP. With this background, one can hypothesize that: 


\section{Table 1. History of development of CSR guidelines/regulations in Bangladesh}

Sources: Compiled and rearranged based on Ahmed (2012), Bangladesh Bank (1997, 2005, 2008, 2010, 2011a, 2011b, 2011c, 2012, 2017), and BSEC (2012).

\begin{tabular}{|c|c|c|c|}
\hline Year & Events & Purpose/Effect & Impact on banks \\
\hline 1993 & $\begin{array}{l}\text { Lending Risk Analysis (LRA) by } \\
\text { FSRP }\end{array}$ & $\begin{array}{l}\text { First regulatory initiatives in mainstreaming best } \\
\text { practices in credit management operations of } \\
\text { banks }\end{array}$ & $\begin{array}{l}\text { ESG and CSR aspects were not } \\
\text { addressed }\end{array}$ \\
\hline 1995 & $\begin{array}{l}\text { Department of Environment } \\
\text { (DOE) issued Environmental } \\
\text { Conservation Act }\end{array}$ & $\begin{array}{l}\text { Environmental conservation was mainstreamed by } \\
\text { having a provision for that }\end{array}$ & $\begin{array}{l}\text { First regulatory initiatives that } \\
\text { asked banking sector to address } \\
\text { environmental aspects }\end{array}$ \\
\hline 1997 & $\begin{array}{l}\text { Environment Conservation } \\
\text { Rules by the Department of } \\
\text { Environment }\end{array}$ & $\begin{array}{l}\text { A certificate of Environmental Clearance was made } \\
\text { compulsory }\end{array}$ & $\begin{array}{l}\text { Central Bank fostered environmental } \\
\text { compliance in the banking sector }\end{array}$ \\
\hline 1997 & $\begin{array}{l}\text { Circular on Environmental } \\
\text { Compliance by Bangladesh Bank } \\
\text { (BRPD Circular No. } 12,1997 \text { ) }\end{array}$ & $\begin{array}{l}\text { Two purposes were clear out of this Central Bank } \\
\text { directive: } \\
\text { - ask banks to comply with the Environmental } \\
\text { Conservation Rules, 1997; } \\
\text { - address pollution issues related to the } \\
\text { financing process of banks }\end{array}$ & $\begin{array}{l}\text { For the first time in Bangladesh, } \\
\text { banks were held to be responsible } \\
\text { for their activities related to } \\
\text { environmental issues }\end{array}$ \\
\hline 2005 & $\begin{array}{l}\text { Credit Risk Grading Manual } \\
\text { (CRGM) by Bangladesh Bank }\end{array}$ & $\begin{array}{l}\text { Lending Risk Analysis guidelines were replaced } \\
\text { by the CRGM, which are more detailed policy } \\
\text { guidelines }\end{array}$ & $\begin{array}{l}\text { Social and environmental risks } \\
\text { were not considered in this policy } \\
\text { guidelines }\end{array}$ \\
\hline 2008 & $\begin{array}{l}\text { Guideline on Corporate Social } \\
\text { Responsibility by Bangladesh } \\
\text { Bank (DOS Circular No. 1, 2008) }\end{array}$ & $\begin{array}{l}\text { Social and environmental risks assessment were } \\
\text { introduced in loan screening process }\end{array}$ & $\begin{array}{l}\text { In light of social and environmental } \\
\text { aspects, responsible banking } \\
\text { practices were introduced in the } \\
\text { banking sector }\end{array}$ \\
\hline 2010 & $\begin{array}{l}\text { Review of CSR Initiatives in banks } \\
\text { ( } 2008 \text { and 2009) by Bangladesh } \\
\text { Bank }\end{array}$ & $\begin{array}{l}\text { Bangladesh Bank evaluated and reported } \\
\text { Corporate Social Responsibilities performed by the } \\
\text { banks for 2008-2009 }\end{array}$ & $\begin{array}{l}\text { A stress was on the banking sector in } \\
\text { mainstreaming CSR activities within } \\
\text { their operations }\end{array}$ \\
\hline 2011 & $\begin{array}{l}\text { Environmental Risk Management } \\
\text { (ERM) Guidelines for Banks } \\
\text { and Financial Institutions in } \\
\text { Bangladesh }\end{array}$ & $\begin{array}{l}\text { Assessment and incorporation of deteriorating } \\
\text { environmental effects within the interests of } \\
\text { financial institutions (Bangladesh Bank, 2011f) }\end{array}$ & $\begin{array}{l}\text { Environmental issues were clearly } \\
\text { incorporated by the financial } \\
\text { institutions }\end{array}$ \\
\hline 2011 & $\begin{array}{l}\text { Policy Guidelines for Green } \\
\text { Banking by Bangladesh Bank }\end{array}$ & $\begin{array}{l}\text { Banks required to form a committee with directors } \\
\text { to oversee "environmental policies, strategies and } \\
\text { program" (Bangladesh Bank, 2011b) }\end{array}$ & $\begin{array}{l}\text { Formulating accountability and } \\
\text { responsibility within the governing } \\
\text { body regarding green and } \\
\text { environmental activities of banks }\end{array}$ \\
\hline 2011 & $\begin{array}{l}\text { Review of CSR Initiatives in banks } \\
\text { (2010) by Bangladesh Bank }\end{array}$ & $\begin{array}{l}\text { Bangladesh Bank evaluated and reported } \\
\text { Corporate Social Responsibilities performed by the } \\
\text { banks for } 2010\end{array}$ & $\begin{array}{l}\text { Stress was given on more broader } \\
\text { and deeper aspects of CSR activities }\end{array}$ \\
\hline 2012 & $\begin{array}{l}\text { Mainstreaming Corporate Social } \\
\text { Responsibility (CSR) in Financial } \\
\text { Institutions }\end{array}$ & $\begin{array}{l}\text { Financial institutions were directed to submit a } \\
\text { report to Bangladesh Bank regarding ensuring } \\
\text { gender equality as part of CSR initiatives }\end{array}$ & $\begin{array}{l}\text { Fls are targeted to comply with } \\
\text { gender equality }\end{array}$ \\
\hline 2012 & $\begin{array}{l}\text { Securities and Exchange } \\
\text { Ordinance (Amendment } \\
\text { Notification) }\end{array}$ & $\begin{array}{l}\text { Strengthen governance through appropriate } \\
\text { structures and roles of board of directors, internal } \\
\text { and external auditors, and clearer guidelines for } \\
\text { reporting and compliance of corporate governance }\end{array}$ & $\begin{array}{l}\text { Stringent regulatory pressure for } \\
\text { complying to more transparent and } \\
\text { standardized governance policies }\end{array}$ \\
\hline 2017 & $\begin{array}{l}\text { Guidelines on } \\
\text { Environmental \& Social Risk } \\
\text { Management (ESRM) for } \\
\text { banks and financial institutions in } \\
\text { Bangladesh }\end{array}$ & $\begin{array}{l}\text { In addition to expansion of the scope of } \\
\text { environmental risk evaluation guidelines, focus was } \\
\text { put on incorporating a number of social parameters }\end{array}$ & $\begin{array}{l}\text { To replace the subjectivity of } \\
\text { the previous ERM guidelines, } \\
\text { quantitative risk rating system was } \\
\text { introduced, which helped banks to } \\
\text { embrace a standardized assessment } \\
\text { method }\end{array}$ \\
\hline
\end{tabular}




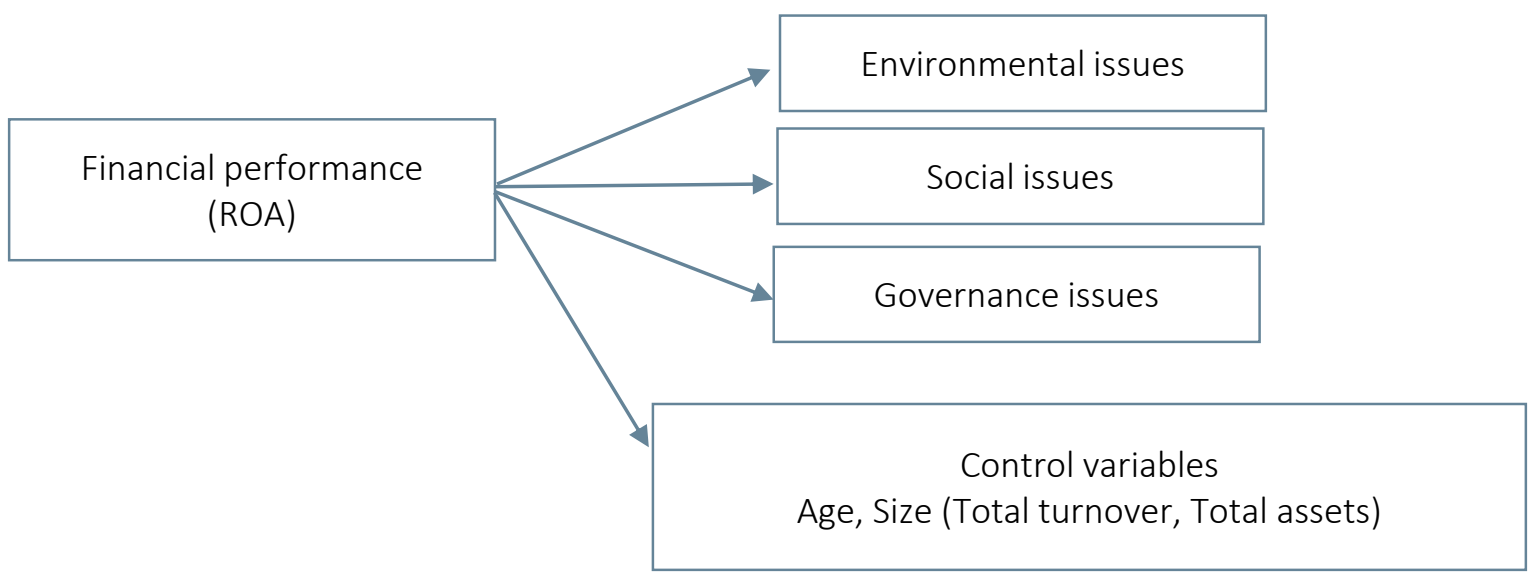

Figure 1. Conceptual framework

H: Compliance to the ESG policy framework or, in other words, having higher ESG (Environmental, Social and Governance) score results in higher financial performance.

Consequently, the developed model is as follows:

Financial Performance $(\mathrm{ROA})=f($ Environmental, Social, Governance Factors, Control Variables)

\section{METHODOLOGY}

\subsection{ESG score calculations}

Given various aspects of the constructs - environmental, social and governance - a primary survey instrument was developed. The areas assessing the dimensions of the ESG constructs include items covering existing position, current practices to forthcoming prospects of these factors embedded in banks' credit approval and management processes (Ahmed, et al., 2014). Several research and policy papers (Thompson \& Cowton, 2000; EP,
2014; UNEP, 2007; Bangladesh Bank, 2011a) were consulted in developing the survey instrument. A five-point Likert Scale was used to calculate the scores for the ESG factors, where higher score denotes better performance for a bank. Maximum score a bank can have in all categories is 160 and minimum is 32 (Table 2).

\subsection{Data and sampling}

Under the Bangladesh Bank Order, 1972, and the Bank Company Act, 1991, there are 59 scheduled banks operating in Bangladesh and regulated by Bangladesh Bank. There are 41 private commercial banks (PCBs), out of which 30 PCBs were selected for this study. As the purpose of the study is to observe the effects of policy developments since mid ' 90 s onwards, the relatively new banks were discarded from this study. A random sampling method was used where the questionnaires were filled in by three key officials working in credit department in branches of the respective banks. Three persons per bank of 30 banks total 90 as the sample size. Subsequently, data triangulation was

Table 2. ESG score calculations

\begin{tabular}{|c|c|c|c|c|c|}
\hline Risk factor & $\begin{array}{l}\text { No. of } \\
\text { items }\end{array}$ & Sample items & Likert scale & $\begin{array}{l}\text { Min. } \\
\text { score }\end{array}$ & $\begin{array}{l}\text { Max. } \\
\text { score }\end{array}$ \\
\hline Environmental & 16 & $\begin{array}{l}\text { Compliance issues; geographic position; resilience to } \\
\text { climate change; waste management; efficient energy usage; } \\
\text { overall pollution control (e.g., sound, air) }\end{array}$ & 1 to 5 & 16 & 80 \\
\hline Social & 10 & $\begin{array}{l}\text { Working conditions; participatory management; } \\
\text { compensation fairness; opportunity for self-development; }\end{array}$ & 1 to 5 & 10 & 50 \\
\hline Governance & 6 & $\begin{array}{l}\text { Organizational structure; overall disclosure policies (e.g. } \\
\text { CSR); fair audit practices }\end{array}$ & 1 to 5 & 6 & 30 \\
\hline \multicolumn{4}{|l|}{ Total } & 32 & 160 \\
\hline
\end{tabular}


conducted from secondary sources to ensure validity of the data. The typical secondary sources included banks' websites, publicly disclosed reports, news on the media, regulatory and legal notices.

\subsection{Variables}

Typically, financial performance (FP) is usually measured by a ratio of ROE (Return on Equity) or ROA (Return on Assets) or both. Given the fact that in Bangladesh, the calculations of ROE often differ between firms, ROA was selected to be a better proxy for the FP for this study. Particularly, inconsistencies among ROE values is a contextual issue, which arises due to a common practice of varying ways of measuring equity by different firms in Bangladesh. Whereas, the calculations for ROA are steady and standardized for all firms in Bangladesh. Everyone follows a standard formula - net income divided by the total assets - to calculate ROA in Bangladesh. Apart from ROE or ROA, capital market-based indicators (e.g., market-to-book ratio) are often taken as measure of FP of firms in different countries. However, as the capital market of Bangladesh fluctuates quite often, it would be imprudent to take such an indicator to measure FP. Hence, ROA is used as a proxy for the financial performance of firms for this study. It should be noted that many other studies also used ROA to measure performance of financial management aspects of firms (Waddock \& Graves, 1997; McGuire et al., 1988; Johnson \& Greening, 1999). Besides the dependent variable (ROA), a set of control variables is usually included in a model to single out the influences of the presumed factors on the dependent variable. In this study, two control variables, size and age, are incorporated in the model, where size was measured from total assets and turnover of firms. As mentioned earlier, the ESG score was measured from the primary data through survey instrument.

\section{RESULTS}

\subsection{Descriptive statistics and correlogram}

Comparative status of the descriptive statistics and correlation coefficients are summarized in Table 3 and Table 4. Average return on assets has decreased to 0.7 percent in 2018 from 1.13 percent in 2012. Age of the banks remained near to 20 years with minimum-maximum range increasing to 9 to 34 years, respectively. There was a huge spread in the high-low volume of turnover (TRN) and total assets (TOA). Natural log of the both was taken to reduce variation in data analysis.

There was a sharp rise in the mean environmental social and governance (ESG) score to 177 in 2018 from 132 in 2012. Individual score in environmental, social and governance risk factors also went up considerably. The most significant increase was in governance score, where there was a 25 percent rise in the score in 2018 compared to 2012. Introduction of various new policy guidelines with regard to sustainable investment decisions could help to achieve this progress.

However, overall, the correlation analysis showed a very weaker relationship between profitability (ROA) and sustainability (ESG) in 2018 compared

Table 3. Descriptive statistics and Pearson correlations (2012) (reproduced with permission from Specify the source)

\begin{tabular}{|c|c|c|c|c|c|c|c|c|c|c|c|c|c|c|}
\hline \multirow{2}{*}{\multicolumn{2}{|c|}{ Variables }} & \multirow{2}{*}{$\mathbf{N}$} & \multirow{2}{*}{ Mean } & \multirow{2}{*}{ Min. } & \multirow{2}{*}{ Max. } & \multirow{2}{*}{ S.D. } & \multicolumn{8}{|c|}{ Correlogram } \\
\hline & & & & & & & ROA & ESG & ENS & SOS & GNS & AGE & TRN & TOA \\
\hline$R O A$ & Return on assets & 30 & 1.13 & -10.09 & 3.90 & 13.41 & 1 & & & & & & & \\
\hline ESG & $\begin{array}{l}\text { Environmental, social } \\
\text { and governance score }\end{array}$ & 30 & 132.33 & 94.00 & 160.00 & 20.41 & $583^{* *}$ & 1 & & & & & & \\
\hline$E R F$ & $\begin{array}{l}\text { Environmental risk } \\
\text { factor }\end{array}$ & 30 & 66.50 & 42.00 & 82.00 & 12.11 & $.603 * *$ & $.994 * *$ & 1 & & & & & \\
\hline SRF & Social risk factor & 30 & 45.40 & 34.00 & 54.00 & 6.82 & $.542 * *$ & $.983 * *$ & $958^{* *}$ & 1 & & & & \\
\hline$G R F$ & Governance risk factor & 30 & 20.43 & 18.00 & 24.00 & 1.74 & $.518^{* *}$ & $.961 * *$ & $.945 * *$ & $.943 * *$ & 1 & & & \\
\hline$A G E$ & Age of the bank & 30 & 20.67 & 11.00 & 53.00 & 10.77 & .021 & .282 & .257 & .301 & .340 & 1 & & \\
\hline TRN & Total turnover & 30 & 637.03 & 43.74 & 1800.00 & 328.34 & $.433^{*}$ & $.467 * *$ & $.476^{* *}$ & $.452 *$ & $.394 *$ & .188 & 1 & \\
\hline TOA & Total assets ${ }^{\ddagger}$ & 30 & 10684.53 & 1503.59 & 37022.71 & 6189.15 & .348 & $.397^{*}$ & $.401^{*}$ & $.390 *$ & .337 & .266 & $.962 * *$ & 1 \\
\hline
\end{tabular}

Note: ${ }^{\ddagger}$ Expressed in 10 million of BDT (Bangladesh Taka), $* p<0.05 ; * * p<0.01$. 
Table 4. Descriptive statistics and Pearson correlations (2018)

\begin{tabular}{|c|c|c|c|c|c|c|c|c|c|c|c|c|c|c|}
\hline \multirow{2}{*}{\multicolumn{2}{|c|}{ Variables }} & \multirow{2}{*}{$\mathbf{N}$} & \multirow{2}{*}{ Mean } & \multirow{2}{*}{ Min. } & \multirow{2}{*}{ Max. } & \multirow{2}{*}{ S.D. } & \multicolumn{8}{|c|}{ Correlogram } \\
\hline & & & & & & & ROA & ESG & ENS & SOS & GNS & AGE & TRN & TOA \\
\hline$R O A$ & Return on assets & 30 & .72 & -3.44 & 1.77 & .88 & 1 & & & & & & & \\
\hline ESG & $\begin{array}{l}\text { Environmental, social } \\
\text { and governance score }\end{array}$ & 30 & 176.55 & 113.22 & 260.00 & 29.75 & .047 & 1 & & & & & & \\
\hline$E R F$ & $\begin{array}{l}\text { Environmental risk } \\
\text { factor }\end{array}$ & 30 & 70.35 & 47.00 & 79.00 & 9.17 & .044 & 1 & & & & & & \\
\hline SRF & Social risk factor & 30 & 36.55 & 16.00 & 48.00 & 8.80 & .066 & $.639 * *$ & 1 & & & & & \\
\hline GRF & Governance risk factor & 30 & 25.63 & 21.33 & 30.00 & 2.39 & -.039 & .309 & $.510^{* *}$ & 1 & & & & \\
\hline$A G E$ & Age of the bank & 30 & 20.13 & 9.00 & 34.00 & 8.88 & -.249 & $-.392 *$ & -.158 & -.076 & -.123 & 1 & & \\
\hline TRN & Total turnover ${ }^{\ddagger}$ & 30 & 23.93 & 18.00 & 31.00 & 2.79 & .223 & -.298 & -.269 & .169 & -.038 & .177 & 1 & \\
\hline TOA & Total assets ${ }^{\mp}$ & 30 & 26.13 & 23.00 & 28.00 & .89955 & $470 * *$ & -.156 & -.071 & -.081 & .006 & .179 & $.471^{* *}$ & 1 \\
\hline
\end{tabular}

Note: ${ }^{\ddagger}$ Expressed in 10 million of BDT (Bangladesh Taka), ${ }^{*} p<0.05 ; * * p<0.01$.

to 2012 (see Table 4). Also, governance and age of the banks are showing a negative relationship with ROA. This indicates that sustainability factors and control variables, except total assets, can have low degree of influence on profitability (ROA). This relationship was further clarified in the following regression analysis.

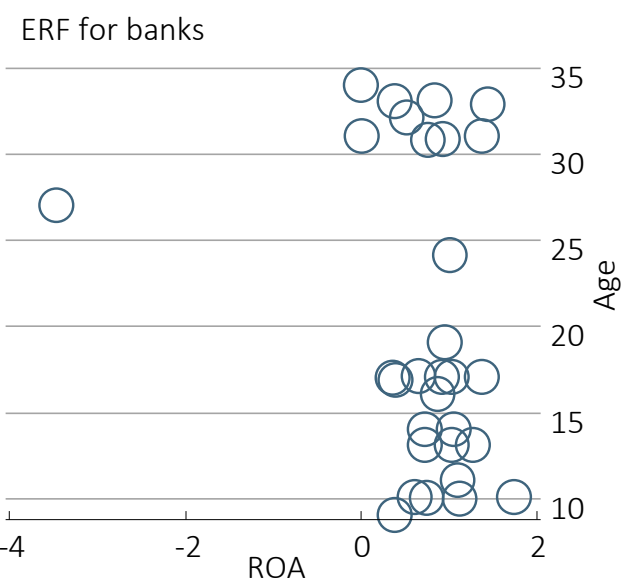

GRF for banks

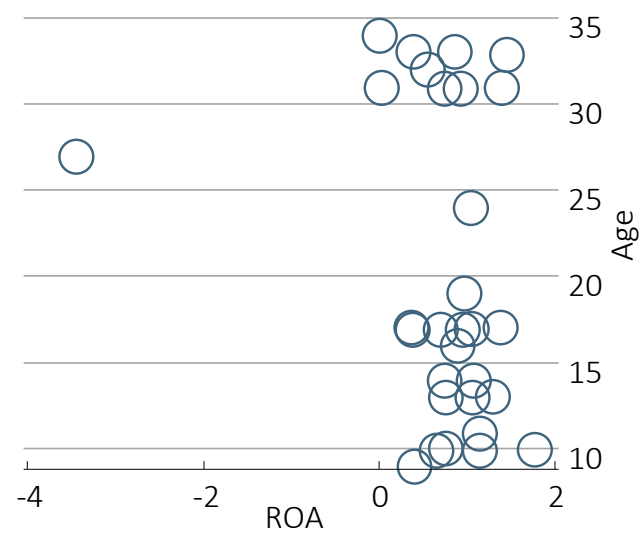

\subsection{Graphical analysis}

Scatter plotting of environmental, social and governance (ESG) scores against return on assets (ROA) and age of the banks is shown in Figure 2. It can be observed that the scores are clustered around 0 to 2 percent return on assets. Whereas,

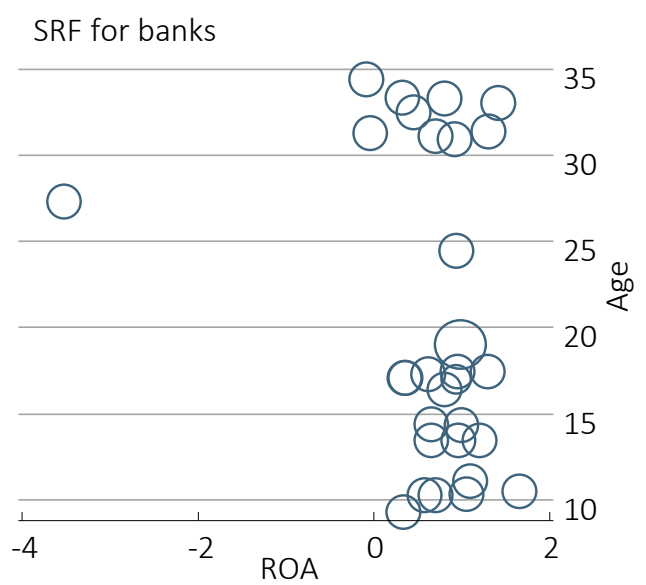

ESG for banks

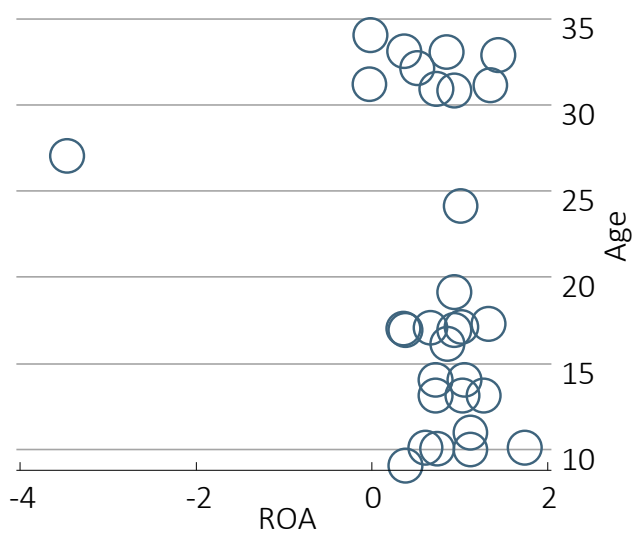

Figure 2. Scatter plotting of ESG scores with ROA and Age 
in terms of age of the banks, high ESG scores are huddled in between 30 to 35 years. It can be concluded that first-generation banks are more sustainable by being ESG compliant. This finding can be examined further in the regression analysis.

\subsection{Regression analysis}

The hypothesis formulated earlier was tested using regression analysis. Tables 5 to 8 present the comparative results of the regression analysis between 2012 and 2018. Eight models were constructed to test the impact of switching sustainability factors and control variables on the dependent variable profitability. In all the models, return on assets (ROA) has been used as the dependent variable and three risk factors, environmental, social, and governance, were used as a proxy for sustainability swapped with control variables such as age, turnover and total assets.

In Model 1 shown in Table 6, total ESG scores of the banks were taken as the proxy for sustainability controlled for age and turnover as the proxy for size. The model revealed a positive insignificant relationship between ROA and ESG as well as turnover and age $(\mathrm{P}>10)$. The coefficient of determination $\left(R^{2}\right)$ was very low $(0.14)$. This was in contrast to what happened in 2012, when ESG showed a positive significant relationship with return on assets (see Table 5).

Model 2 swapped total assets as the proxy for size instead of turnover. Other variables remained the same, the result improved slightly. When other factors are held constant, age showed a negative and total assets showed a positive significant relationship with return on assets $(p<0.01)$. The coefficient of determination $\left(R^{2}\right)$ went up (0.34). However, ESG still showed positive but insignificant relationship with return on assets. The findings of this model are again in contrast to what was found in 2012, where ESG showed a positive and significant relationship with return on assets (see Table 5).

Models 3 to 5 used individual environmental, social, and governance risk factor scores to see the

Table 5. Results of regression analysis for ESG as an independent variable (2012)

\begin{tabular}{|c|c|c|}
\hline Variables & Model 1( $\beta)$ & Model $2(\beta)$ \\
\hline \multicolumn{3}{|l|}{ Dependent } \\
\hline \multicolumn{3}{|l|}{ Return on total assets (ROA) } \\
\hline \multicolumn{3}{|l|}{ Independent } \\
\hline Environmental, social and governance (ESG) scores & $.058^{* *}$ & $.062 * *$ \\
\hline \multicolumn{3}{|l|}{ Control } \\
\hline AGE & -.035 & -.038 \\
\hline TRN & .001 & \\
\hline TOA & & .000 \\
\hline Adj. $R^{2}$ & .33 & .32 \\
\hline $\mathrm{F}$ & 1.587 & 5.451 \\
\hline
\end{tabular}

Note: $* * p<.01$.

Table 6. Results of regression analysis for ESG as an independent variable (2018)

\begin{tabular}{|c|c|c|}
\hline Variables & Model 1( $\beta)$ & Model $2(\beta)$ \\
\hline \multicolumn{3}{|l|}{ Dependent } \\
\hline \multicolumn{3}{|l|}{ Return on total assets (ROA) } \\
\hline \multicolumn{3}{|l|}{ Independent } \\
\hline Environmental, social and governance (ESG) scores & .001 & 0.000 \\
\hline \multicolumn{3}{|l|}{ Control } \\
\hline AGE & -.029 & $-.034 * *$ \\
\hline TRN & .088 & \\
\hline TOA & & $.522 * *$ \\
\hline Adj. $R^{2}$ & .136 & .336 \\
\hline $\mathrm{F}$ & 1.367 & 4.378 \\
\hline
\end{tabular}

Note: ${ }^{* *} p<.01$. 
Table 7. Results of regression analysis for environmental, social, and governance scores as independent variables controlled for size (2012)

\begin{tabular}{|c|c|c|c|c|c|c|}
\hline Variables & Model 3( $\beta)$ & Model 4( $\beta)$ & Model 5( $\beta)$ & Model 6( $\beta)$ & Model $7(\beta)$ & Model 8( $\beta)$ \\
\hline \multicolumn{7}{|l|}{ Dependent } \\
\hline \multicolumn{7}{|l|}{ Return on total assets (ROA) } \\
\hline \multicolumn{7}{|l|}{ Independent } \\
\hline Environmental, risk factor (ERF) & $.100 * *$ & & & $.107 * *$ & & \\
\hline Social risk factor (SRF) & & $.157 *$ & & & $.170 * *$ & \\
\hline Governance risk factor (GRF) & & & $.603^{*}$ & & & $.655^{*}$ \\
\hline \multicolumn{7}{|l|}{ Control $-\cdots$} \\
\hline AGE & -.032 & -.035 & -.040 & -.035 & -.039 & -.044 \\
\hline TRN & .001 & .002 & $.002^{+}$ & & & \\
\hline TOA & & & & .000 & .000 & .000 \\
\hline Adj. $R^{2}$ & .35 & .29 & .29 & .33 & .27 & .27 \\
\hline $\mathrm{F}$ & 6.109 & 4.970 & 4.925 & 5.846 & 4.610 & 4.494 \\
\hline
\end{tabular}

Note: $* \mathrm{p}<.05 ; * * \mathrm{p}<.01$.

Table 8. Results of regression analysis for environmental, social, and governance scores as independent variables controlled for size (2018)

\begin{tabular}{|c|c|c|c|c|c|c|}
\hline Variables & Model $3(\beta)$ & Model $4(\beta)$ & Model $5(\beta)$ & Model $6(\beta)$ & Model $7(\beta)$ & Model $8(\beta)$ \\
\hline \multicolumn{7}{|l|}{ Dependent } \\
\hline \multicolumn{7}{|l|}{ Return on total assets (ROA) } \\
\hline \multicolumn{7}{|l|}{ Independent } \\
\hline Environmental, risk factor (ERF) & .001 & & & -.001 & & \\
\hline Social risk factor (SRF) & & .010 & & & .005 & \\
\hline Governance risk factor (GRF) & & & -.041 & & & -.008 \\
\hline \multicolumn{7}{|l|}{ Control } \\
\hline AGE & -.029 & -.028 & $-.031 \dagger$ & $-.035^{+}$ & $-.033^{*}$ & $-.034^{*}$ \\
\hline TRN & .088 & .095 & .094 & & & \\
\hline TOA & & & & $.522 *$ & $.525^{* *}$ & $.521^{* *}$ \\
\hline Adj. $R^{2}$ & .136 & .145 & .148 & .25 & .26 & .26 \\
\hline $\mathrm{F}$ & 1.364 & 1.473 & 1.505 & 4.379 & 4.428 & 4.388 \\
\hline
\end{tabular}

Note: ${ }^{\dagger} \mathrm{p}<.10 ;^{*} \mathrm{p}<.05$ * $^{* *} \mathrm{p}<.01$.

impact of sustainability initiatives of the banks on profitability (ROA). In all these models, turnover was used as the proxy for size. No significant relationship was found between the environmental (model 3), social (model 4), and governance (model 5) factors with return on assets (see Table 8). Also, none of the control variables had any significant relationship with return on assets, except age in model $5(p<.10)$. These results are again inconsistent with what was found in 2012 data, where all the individual risk factors showed a positive and significant relationship with the dependent variable, return on assets (see Table 7).

Table 8 also depicts the findings of models 6 to 8 . Total assets were used as a substitute for size, and respective environmental, social, and governance risk factor scores were used to relate with return on assets. None of the sustainability risk factors came out to have a significant relationship with return on assets. However, control variable age was negatively significant in models 7 and $8(\mathrm{p}<.05)$, while total assets had a significant positive relationship in all the three models. The coefficient of determination $\left(R^{2}\right)$ increased (.26) compared to models using turnover as the proxy for size. The findings are again inconsistent with that of 2012, where all the individual ESG risk factors were positively and significantly related with return on assets by taking total assets as a proxy for size (see Table 7).

\section{DISCUSSION}

This study was conducted with twofold objectives in mind. First, to see whether policy guidelines initiated since 2012 had an impact on ESG performance; second, to see whether this performance had any impact on financial performance. 
As far as the first objective is concerned, it was observed that individual environmental and governance risk scores went up by 6 percent and 25 percent in 2018, respectively. Surprisingly, social risk score went down by 19 percent in the same year. However, total ESG score of banks went up by approximately 33 percent in 2018 compared to the same in 2012.

One reason behind the improvement of the governance score could be the increased disclosure on governance required by the central bank following the liquidity and debt crisis faced by the sector throughout the last few years. Bank directors and chairmen were exposed in being part of politics and other unethical activities, lending out loans to debtors who would otherwise not be viable for loans (Rashid, 2018). This impaired the image of the sector and, to solve this problem, the central bank soon increased the disclosure requirements for all banks across the country. The increased strictness of the Bangladesh Bank as per reporting requirements from banks even leads to improved corporate governance aided by amendment of Securities and Exchange (SEC) Ordinance in 2012. This required the directors of banks to meet all their stakeholders and discuss relevant issues and to instruct them to become a more legally compliant bank.

The improvement of the environmental performance could be due to the introduction of Guidelines on Environmental \& Social Risk Management (ESRM) for Banks and Financial Institutions in Bangladesh in 2017 and methodical implementation of Policy Guidelines for Green Banking by Bangladesh Bank in three phases ending on June 2015. This finding is consistent with (Ahmed et al., 2017), whose study conducted on 148 listed companies on the Dhaka Stock Exchange (DSE) found that introduction of new policy guidelines significantly improved sustainability performance of the listed firms. The area of banking sector that did not witness significant improvement was a social score since 2012, as there were also many non-performing loans in the banking sector (Khatun, 2018). All that meant that the banking sector was left with less to spend on CSP activities due to channeling considerable amount of resources to solve non-performing loans.

In terms of the second objective, this study did not find significant improvement in the relationship between enhanced ESG performance and profitability. The formulated hypothesis that the higher ESG (Environmental, Social and Governance) score leads to higher financial performance was rejected. It was indeed alarming to observe that this relationship even deteriorated in 2018 compared to 2012. There can be several explanations to this inconclusive result. Waddock and Graves (1997), Revelli and Viviani (2015) and Preston and O'Bannon (1997) found inconclusive or neutral association between sustainability and financial performance. Unconvincing result on the link between sustainability and financial performance can be observed due to complexity in measurement of sustainability and failure in isolating the effect on each other (Waddock \& Graves, 1997). Thus transformation of observed positive impact of policy guidelines on ESG performance to financial results might be diluted due to the complex state of the banking sector of Bangladesh accentuated by the bad loan issue.

As mentioned earlier, the banking sector of Bangladesh is seriously hit by bad loans. In December 2018, total default loan in the banking sector of Bangladesh stood at BDT ${ }^{1} 100$ billion, which had eroded this sector's yearly profit by approximately 58 percent in 2018 (TDS, 2019). Fall in profit due to provisioning for bad loans reduced the profitability of banks (average ROA fell to 0.7 percent in 2018 compared to 1.13 percent in 2012). A sharp drop in profitability can negatively affect the translating the dividends of enhanced ESG performance into profitability.

\section{CONCLUSION}

Despite the huge amount of research on the effect of policy-led sustainability initiatives on financial performance, the results have been inconclusive, especially in developing countries. The general impression derived from literature was somewhat complicated, indirect, time-lagged, and unrewarding.

11 USD = Bangladesh Taka (BDT) 85 approximately. 
This study monitored the changes in sustainability-financial performance linkage aided through new policy guidelines, by conducting a comparative study (2012 and 2018) on 30 private commercial banks in Bangladesh. The findings suggest that introduction of policy guidelines improved the sustainability (environmental and governance) of the banks. However, conversion of this performance into better financial performance could not be confirmed. Complexity with regard to the calculation of ESG score, time-lag in conversion of sustainability performance into financial performance and challenging climate of the banking sector of Bangladesh due to non-performing loans were identified as the probable causes for this inconclusive linkage.

However, like other studies, this research is not also free from limitations. The first and foremost limitation is the simplicity of the methodology used in the study. This is done to allow the data to speak for itself without significant change to achieve a specific goal. Another limitation is non-inclusion of state owned banks (SOB) in Bangladesh. One possible explanation to this is due to the specific ownership nature of these banks, they have a completely different approach to the profitability and sustainability. Mixing SOBs with PCBs can distort the results. Thus, the results of the study do not apply to the entire banking sector of Bangladesh. Future studies may include these to assess the difference.

\section{REFERENCES}

1. Ahmed, S. U. (2012). Green Banking: Advancement and Opportunities. Keiei to Keizai, 92(1-2), 1-13. Retrieved from http://docplayer.net/158749317 Green-banking-advancementand-oppo.html

2. Ahmed, S. U., Islam, M. Z., Mahtab, H., \& Hasan, I. (2014). Institutional Investment and Corporate Social Performance: Linkage towards Sustainable Development. Corporate Social Responsibility and Environmental Management, 21(1), 1-13. https:// doi.org/10.1002/csr.1298

3. Ahmed, S. U., Sultana, E., Mahtab, H. Islam, M. Z., Hasan, I., Wali Ullah, G. M. and Ahmed, S. P. (2017). Does It Pay To Be Socially Responsible? Comparative Evidence from a Developing Country". Global Business Review, 18(5), pp. 1-21. https://doi. org/10.1177/0972150917710134

4. Aupperle, K. E., Carroll, A. B., \& Hatfield, J. D. (1985). An empirical examination of the relationship between corporate social responsibility and profitability. Academy of Management Journal, 28(2), 446-463. Retrieved from https://www.jstor.org/stable/256210

5. Bangladesh Securities and Exchange Commission (BSEC).
(2012). Securities and Exchange Ordinance (Amendment Notification). Retrieved from http://www.mccibd.org/images/ uploadimg/act_and_policy/capital_market/F-01.pdf

6. Barua, S., \& Ahamed, H. (2016). Role of Financial Sector to support SDGS in Bangladesh. Research and Innovation Lab, Royal Capital Limited. Retrieved from https:// d30fl32nd2baj9.cloudfront.net/ incoming/2016/03/30/special-issue---role-of-bd-financial-sectorin-sdgs.pdf/BINARY/Special $\% 20$ Issue $\% 20-\% 20$ Role $\% 20$ of $\% 20$ BD\%20Financial\%20Sector\%20 in\%20SDGs.pdf

7. Bangladesh Bank. (1997). Environmental Compliance of Banks (BRPD Circular No. 12, 1997). Dhaka: Bangladesh Bank.

8. Bangladesh Bank. (2005). Credit Risk Grading Manual. Dhaka: Bangladesh Bank. Retrieved from https://www.Bangladesh Bank.org. bd/mediaroom/circulars/brpd/ dec1105brpd18enl.pdf

9. Bangladesh Bank. (2008). Mainstreaming Corporate Social Responsibility (CSR) in banks and financial institutions in Bangladesh (DOS Circular No. 1, 2008). Dhaka: Bangladesh Bank. Retrieved from https://www.Bangladesh Bank.org.bd/mediaroom/ circulars/dos/jun0108dos01e.pdf
10. Bangladesh Bank. (2010). Review of CSR Initiative in Banks (2008 \& 2009). Dhaka: Bangladesh Bank. Retrieved from https://www. academia.edu/16462778/Review_ of_CSR_Initiatives_in_Banks_2008_ and_2009_

11. Bangladesh Bank. (2011a). Environmental Risk Management (ERM). Guidelines for Financial Institutions in Bangladesh. Dhaka: Bangladesh Bank. Retrieved from https://www.Bangladesh Bank.org. bd/aboutus/regulationguideline/ jan302011erm.pdf

12. Bangladesh Bank. (2011b). Policy Guidelines for Green Banking (BRPD Circular No. 2, February 2011). Dhaka: Bangladesh Bank. Retrieved from https://www.Bangladesh Bank. org.bd/mediaroom/circulars/brpd/ feb272011brpd02e.pdf

13. Bangladesh Bank. (2011c). Review of CSR Initiative in Banks (2010). Dhaka: Bangladesh Bank. Retrieved from https://www.Bangladesh Bank. org.bd/pub/annual/csr/csrjuly2011. pdf

14. Bangladesh Bank. (2012). Mainstreaming Corporate Social Responsibility (CSR) in Financial Institutions (DFIM Circular Letter No. 02). Dhaka: Bangladesh Bank. Retrieved from https://www.Bangladesh Bank.org.bd/mediaroom/ circulars/fid/jan092012fidl02e.pdf 
15. Bangladesh Bank. (2017). Guidelines on Environmental \& Social Risk Management (ESRM) for Banks and Financial Institutions in Bangladesh. Dhaka: Bangladesh Bank. Retrieved from https://www.Bangladesh Bank.org. bd/aboutus/regulationguideline/ esrm_guideline_feb2017.pdf

16. Benabou, R., \& Tirole, J. (2010). Individual and Corporate Social Responsibility. Economica, 77(305), 1-19. https://doi.org/10.1111/j.14680335.2009.00843.x

17. Byron, R. K. (2011). BANGLADESH BANK draws green banking roadmap. The Daily Star, February 28, 2011. Retrieved from https://www.thedailystar.net/ news-detail-175809

18. Cochran, P. L., \& Wood, R. A. (1984). Corporate Social Responsibility and Financial Performance. Academy of Management Journal, 27(1), 42-56. Retrieved from https://www.jstor. org/stable/255956

19. Coffey, B., \& Frywell, G. (1991). Institutional ownership of stock and dimensions of corporate social performance: An empirical examination. Journal of Business Ethics, 10(6), 437-444. https://doi. org/10.1007/BF00382826

20. EP. (2014). Guidance to EPFIs on Incorporating Environmental and Social Considerations into Loan Documentation. Equator Principles. Retrieved from https://equatorprinciples.com/wp-content/ uploads/2017/03/ep_guidance_ for_epfis_on_loan_documentation_march_2014.pdf

21. Friedman, M. (1962). Capitalism and Freedom. Chicago: University of Chicago Press. Retrieved from https://www.press.uchicago.edu/ ucp/books/book/chicago/C/ bo18146821.html

22. Gillan, S., Hartzell, J., Koch, A., \& Starks, L. (2010). Firms' Environmental, Social and Governance (ESG) Choices, Performance and Managerial Motivation. Retrieved from http:// www.pitt.edu/ awkoch/ESG\%20 Nov\%202010.pdf
23. Gompers, A., Ishii, J., \& Metrick, A. (2003). Corporate Governance and Equity Prices. Quarterly Journal of Economics, 118(1), 107-55. https://doi. org/10.1162/00335530360535162

24. Graves, B., \& Waddock, S. A (1994). Institutional Owners and Corporate Social Performance. Academy of Management, 37(4), 1034-1046. Retrieved from https:// www.jstor.org/stable/256611

25. Hull, C. E., \& Rothenberg, A. (2008). Firm performance: the interactions of corporate social performance with innovation and industry differentiation. Strategic Management Journal, 29(7), 781-789. https://doi.org/10.1002/ smj.675

26. Jeucken, M., \& Bouma, J. J. (2001). The changing environment of banks. In J. J. Bouma, M. Jeucken, \& L. Klinkers (Eds.), Sustainable Banking - The Greening of Finance, (pp. 24-37). Sheffield: Greenleaf Publishing Limited. Retrieved from https://pravicnabankaenglish.files.wordpress.com/2014/03/ jeucken-the-changing-environment-of-banks.pdf

27. Johnson, R. D., \& Greening, D. W. (1999). The Effects of Corporate Governance and Institutional Ownership Types on Corporate Social Performance. Academy of Management Journal, 42(5), 564576. Retrieved from https://www. jstor.org/stable/256977

28. Khatun, F. (2018, January 2). Bangladesh economy in 2017 and the way forward. Macro Mirror. Retrieved from https:// www.thedailystar.net/opinion/ macro-mirror/bangladesheconomy-2017-and-the-wayforward-1513438

29. McGuire, J. B., Schneeweis, T., \& Branch, B. (1990). Perceptions of firm quality: A cause or result of firm performance. Journal of Management, 16(1), 167-180. https://doi. org/10.1177/014920639001600112

30. McGuire, J. B., Sundgren, A., \& Schneeweis, T. (1988). Corporate Social Responsibility and Firm Financial Performance. Academy of Management Journal, 31(4),
854-872. Retrieved from https:// www.jstor.org/stable/256342

31. McWilliams, A., \& Siegel, D. (2001). Corporate social responsibility: A theory of the firm perspective. Academy of Management Review, 26(1), 117127. https://doi.org/10.5465/ AMR.2001.4011987

32. Moskowitz, M. (1972). Choosing Socially Responsible Stocks. Business and Society, 1, 71-75. Retrieved from https://www. scribd.com/document/47258552/ Choosing-socially-responsiblestocks-Moskowitz-1972

33. Posner, B., \& Schmidt, W. (1984). Values and the American Manager: An Update Updated. California Management Review, 26(3), 202-216. https://doi org/10.2307/41165090

34. Preston, L. E., \& O’Bannon, D. P. (1997). The Corporate Social-Financial Performance Relationship: A Typology and Analysis. Business \& Society, 36(4), 419-430. https://doi org/10.1177/000765039703600406

35. Rashid, M. (2018, January). It's business: Problems in our banking sector. Dhaka Tribune. Retrieved from https://www.dhakatribune. com/business/2018/01/25/business-problems-banking-sector/

36. Revelli, C., \& Viviani, J.-L. (2015) Financial performance of socially responsible investing (SRI): what have we learned? A meta-analysis. Business Ethics: A European Review, 24(2), 158-185. https://doi. org/10.1111/beer.12076

37. Ruf, B. M., Muralidhar, K., Brown, R. M., Janney, J. J., \& Paul, K. (2001). An Empirical Investigation of the Relationship between Change in Corporate Social Performance and Financial Performance: A Stakeholder Theory Perspective. Journal of Business Ethics, 32(2), 143-156. https://doi org/10.1023/A:1010786912118

38. Salzmann, O., Ionescu-somers, A., \& Steger, U. (2005). The Business Case for Corporate Sustainability. European Management Journal, 23(1), 27-36. https://doi. org/10.1016/j.emj.2004.12.007 
39. Shane, P. B., \& Spicer, B. H. (1983). Market response to environmental information produced outside the firm. Accounting Review, 58(3), 521-536. Retrieved from https:// www.jstor.org/stable/246532

40. Simpson, W. G., \& Kohers, T. (2002). The link between corporate social and financial performance: Evidence from the banking industry. Journal of Business Ethics, 35(2), 97-109. https://doi. org/10.1023/A:1013082525900

41. Smith, D. R. (1993) Environmental Risk: Credit Approaches and Opportunities (An Interim Report). United Nations Environment Programme, Geneva.

42. The Daily Star (TDS). (2019) State banks breed default loans in all sectors. The Daily Star, May 29, 2019. Retrieved from https://www. thedailystar.net/business/news/ state-banks-breed-default-loansall-sectors- 1750249

43. Thompson, P., \& Cowton, C. J. (2004). Bringing the Environment into Bank Lending: Implications for Environmental Reporting. The British Accounting Review, 36(2), 197-218. https://doi.org/10.1016/j. bar.2003.11.005

44. Turban, D. B., \& Greening, D. W. (1997). Corporate Social Performance and Organizational Attractiveness to Prospective Employees.
Academy of Management Journal, 40(3), 658-672. https://doi. org/10.5465/257057

45. Uchida, S., Ahmed, S. U., \& Aabed, A. A. (2011). Corporate governance and Firm Performance in the Financial Sector. Annual Review of East Asian Studies, 52, 107-115. Retrieved from https://www.academia.edu/7664778/Corporate_ Governance and_Firm_Performance_in_the_Financial_Sector

46. Ullmann, A. A. (1985). Data in Search of a Theory: A Critical Examination of the Relationships among Social Performance, Social Disclosure, and Economic Performance of U.S. Firms. Academy of Management Journal, 10(3), 540-557. https://doi. org/10.5465/amr.1985.4278989

47. UNEP. (2007). Banking on Value: A New Approach to Credit Risk in Africa (A report of the United Nations Environment Programme Finance Initiative (UNEP FI) African Task Force (ATF)). Retrieved from https://www. unepfi.org/fileadmin/documents/ banking_on_value.pdf

48. Volz, U. (2018). Fostering Green Finance for Sustainable Development in Asia (ADBI Working Paper No. 814). Tokyo: Asian Development Bank Institute. Retrieved from https://www.adb. org/sites/default/files/publication/403926/adbi-wp814.pdf

49. Volz, U., Böhnke, J., Eidt, V., Knierim, L., Richert, K., \& Roeber, G.-M. (2015). Financing the Green Transformation. How to Make Green Finance Work in Indonesia. Houndmills, Basingstoke: Palgrave Macmillan. Retrieved from https://www.palgrave.com/ gp/book/9781137486110

50. Waddock, S. A., \& Graves, S. B. (1997). The Corporate Social Performance-Financial Performance Link. Strategic Management Journal, 18(4), 303-319. https://doi org/10.1002/(SICI)10970266(199704)18:4<303::AIDSMJ869>3.0.CO;2-G

51. Weber, O., Hoque, A., \& Islam, M. A. (2015). Incorporating environmental criteria into credit risk management in Bangladeshi banks. Journal of Sustainable Finance and Investment, 5(1-2), 1-15. https://doi.org/10.1080/2043 0795.2015.1008736

52. Weidenbaum, M., \& Vogt, S. (1987). Takeovers and Stockholders: Winners and Losers. California Management Review, 29(4), 57-168. Retrieved from https://openscholarship. wustl.edu/cgi/viewcontent. cgi article $=1064 \&$ context $=\mathrm{mlw}_{\text {_ }}$ papers 